\section{ON-LINE TUTORIÁLY V UŽIVATELSKÉ PODPOŘE KNIHOVNICKO-INFORMAČNÍCH SLUŽEB VE ZDRAVOTNICKÝCH KNIHOVNÁCH Č́R}

\section{Eva Lesenková, Klára Mašková}

\section{Anotace}

Tutoriály umožňují uživateli rychlý a efektivní návod pro orientaci ve zvoleném tématu a získání velkého množství dovedností a zkušeností během krátké doby a bez učitele.

Cílem příspěvku je upozornit na různé formy a témata, kterým se online tutoriály $v$ českých zdravotnických knihovnách věnují a představit jejich přehled. Tento příspěvek vychází z bakalářské práce, která byla obhájena v lednu 2018 na ÚISK FF UK pod názvem "Analýza tutoriálů pro vyhledávání v informačních zdrojích českých zdravotnických knihoven", jejíž součástí byla analýza četnosti využívání jednotlivých forem tutoriálů [3]. Analýza ukázala, že nejčastěji jsou používány screenshoty, slidecasty a videa. $Z$ hlediska obsahu byly tyto tutoriály rozděleny do pěti tematických skupin, v kterých dominovalo zpracovávání elektronických informačních zdrojů a vyhledávání. Vlastní tutoriály vytvářelo a na webových stránkách prezentovalo pouze devět zdravotnických knihoven (z celkového počtu 124) a dalších pět knihoven odkazovalo na tutoriály z externích zdrojů.

Rozmanitost knihovnicko-informačních služeb knihoven může vést $k$ jejich nepřehlednosti a znesnadnit tak uživatelům jejich využívání. Tutoriály mohou nejen pomoci uživateli v orientaci a knihovnám v propagaci různých typů služeb, ale plní především funkci vzdělávací. Jejich tvorba se s novými technologiemi stává čím dál tím jednodušší, je však důležité správně zvolit jejich formu. Každá z forem má své klady a zápory, každá je vhodná k jinému účelu. Sami uživatelé pak mohou mít různé preference ve zpưsobech učení, tudíž je možné využít více forem tutoriálů $\mathrm{k}$ jednomu tématu.

Národní lékařská knihovna od roku 2010 ve spolupráci s UK provozuje e-learningové kurzy pro neformální vzdělávání lékařských knihovníků. Od roku 2018 se tyto kurzy, na které si již uživatelé zvykli ve formě využívající multimediální prvky, rozšírí o další novinku: on-line tutoriály.

\section{Klíčová slova}

zdravotnické knihovny, instrukce v knihovnách, vzdèlávání uživatelů, tutoriály

\section{1 Úvod}

Informační a komunikační technologie přinášejí změny ve světě informační společnosti a jejího působení na člověka jako uživatele. Uživatelé mají dnes přímý přístup k elektronickým informačním zdrojům, avšak pro cílené vyhledávání je stále potřeba hlubší znalost prostředí a rešeršních metod [6]. V současnosti některé knihovny studentům již neposkytují plnou rešeršní službu, ale usilují o spolupráci se školou v tématech informačního vzdělávání. Průzkum existující literatury v oboru bývá povinnou součástí studijních povinností při zpracování kvalifikačních prací, kde student prokazuje orientaci a znalost zdrojů svého oboru. Vyskytují se nové formy informační podpory, kdy namísto komplexní rešeršní služby jsou studentům nabízeny bezplatné kurzy a workshopy, online podpora či osobní konzultace (např. Moravská zemská knihovna, Národní technická knihovna).

S obtížemi při vyhledávání potřebného zdroje se setkávají nejen studenti, ale i další uživatelé. Knihovny mohou nabízet referenční služby, které uživatelům při vyhledávaní zdrojů pomáhají. Konzultace však může probíhat pouze v otevíracích hodinách a zabere čas jak uživateli, tak knihovníkovi.

Online tutoriály, které jsou dostupné v režimu 24/7 pro všechny uživatele (i ty vzdálené), aniž by byli přítomni v knihovně, jsou možnou variantou efektivní uživatelské podpory. Nejen, že šetří čas uživateli i knihovníkovi, ale mohou také zapojit uživatele s odlišnými styly učení: pozorování, poslech a praktické učení [4]. Uživatelé si mají také možnost nastavit vlastní tempo, či si daný tutoriál podle libosti zopakovat. Online tutoriály mohou být přívětivější pro uživatele, kteří se při osobní komunikaci setkávají s různými bariérami [5]. Jde např́klad o cizince nebo sluchově handicapované.

\section{Formy vizualizace tutoriálů}

Tutoriály by měly splňovat základní prvky slohového postupu návodového. Měly by jasně a stručně poskytnout instrukce jak něco udělat tak, aby bylo dosaženo zadaného cíle [8]. Vytvořené mohou být pomocí textů, obrázků, videa, poprípadě kombinací těchto složek. Vizualizace tutoriálů se dá provést několika způsoby:

\subsection{Snímek obrazovky (screenshot)}

Jde asi o nejjednodušší formu vizualizace, která může být při popisování problému $v$ počítačovém prostředí pro uživatele přivětivější a intuitivnější než prostý text. Snímek obrazovky může být doplněn instruktážními prvky jako například text, šipky či zakroužkování důležitých prvků.

\subsection{Slidecast}

Slidecast je multimediální učební objekt, složený z jednotlivých snímků, které dohromady vytváří film[4]. V podstatě jde o prezentace, které mohou být také nastaveny k automatickému posunu. Na web mohou být umístěny napríklad jako videa na platformě Youtube nebo jako prezentace prostřednictvím sekundární aplikace, jako např́klad Slideshare.

\subsection{Video}

Videa Ize rozdělit do 3 skupin na živé video, video obrazovky nebo animaci. Pro vizualizaci instrukcí především v online prostředí je nejvhodnější video obrazovky (screencast). Pomocí softwaru, který zaznamenává děj na obrazovce, Ize zachytit a uživatelům třeba ukázat, jak pracovat se systémem, softwarovým balíčkem nebo webovými stránkami.

\subsection{Interaktivní video}

Interaktivní video je video doplněno interaktivními prvky, které donutí uživatele vymanit se z pasivní role sledovatele obsahu a umožní mu účastnit se daného materiálu. Mezi interaktivní prvky patří například simulace, hry, provázející obrázky či reagující časové osy. Existují různé formy zapojení uživatele. V některých videích se mohou nacházet pouze odkazy, které odvedou uživatele do jiných částí videa nebo na jiný obsah mimo video. Jiné formy interakce videa pak umožní uživateli prímo se vnořit do videa a řídit jeho děj. Interaktivní videa mají potenciál být efektivnější než statické tutoriály.

\section{Tutoriály ve zdravotnických knihovnách}

V roce 2017 bylo evidováno 124 zdravotnických knihoven z různých typů zdravotnických a vzdělávacích zařízení:

Součástí již zmiňované kvalifikační práce byla analýza, ve které bylo zjištěno, že z celkového počtu 124 zdravotnických knihoven, má 70 knihoven své webové stránky. Pouze 9 zdravotnických knihoven vytváří své vlastní tutoriály a 12 knihoven odkazuje na cizí tutoriály. Nízký počet vlastních tutoriálů může být způsoben také tím, že téměř všechny webové stránky zdravotnických knihoven jsou součástmi webů jejich institucí. Napřiklad webová stránka Lékařské knihovny Fakultní nemocnice v Brně je pouze záložkou na webových stránkách nemocnice (https://www.fnbrno.cz/lekarska-knihovna/k1601). Knihovny pak mohou mít omezený prístup k úpravě svých webových stránek a to jak po formální, tak po obsahové stránce. 


\section{Počet záznamů}

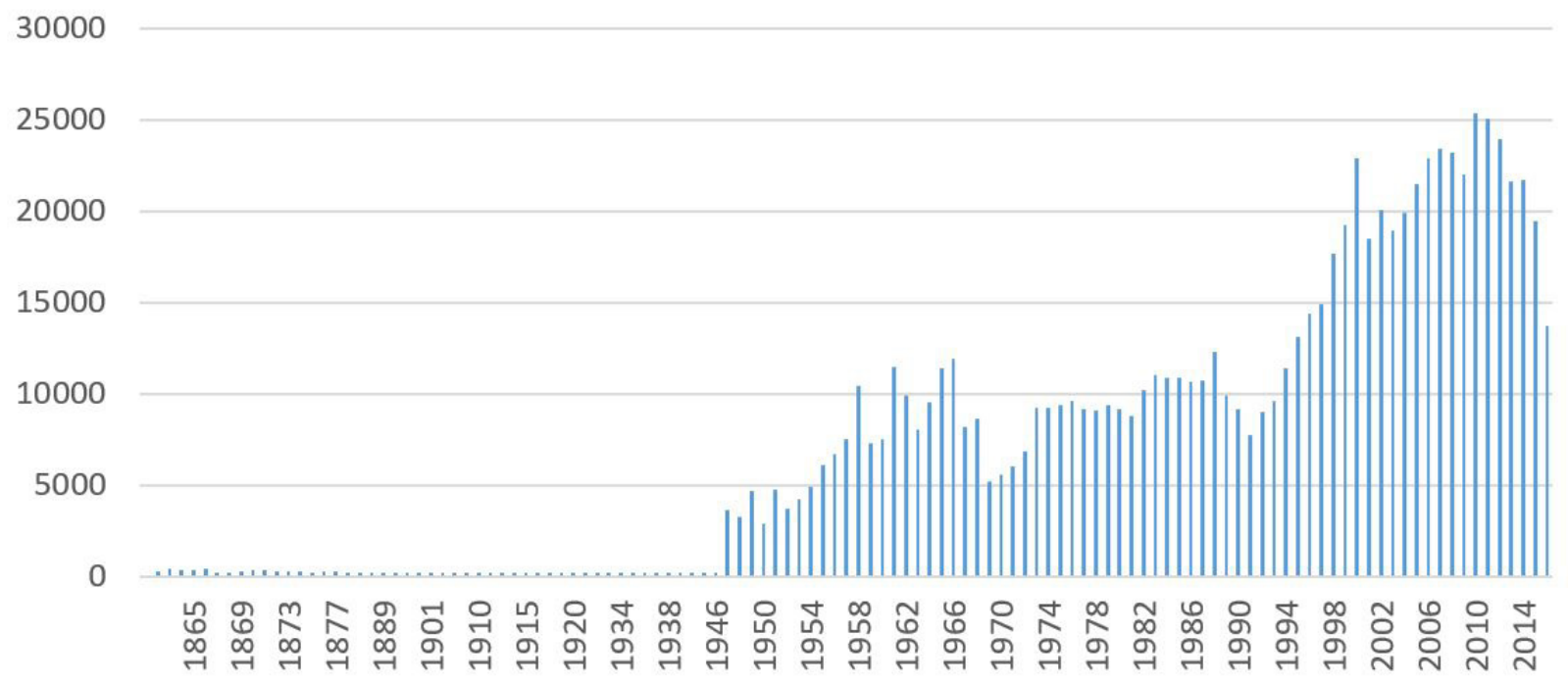

Graf 1

\begin{tabular}{|c|c|c|c|c|c|c|c|}
\hline & Text / screenshot & $\begin{array}{l}\text { Interaktivní } \\
\text { videa }\end{array}$ & Text & Screencast & $\begin{array}{l}\text { Videa } \\
\text { obrazovky }\end{array}$ & Screenshot & Celkem \\
\hline $\begin{array}{l}\text { Masarykova } \\
\text { univerzita } \\
\text { - Knihovna } \\
\text { univerzitního } \\
\text { kampusu }\end{array}$ & 10 & 20 & 0 & 0 & 0 & 0 & 30 \\
\hline $\begin{array}{l}\text { 1. LF UK } \\
\text { a VFN - Ústav } \\
\text { vědeckých } \\
\text { informací }\end{array}$ & 2 & 0 & 0 & 0 & 0 & 0 & 2 \\
\hline $\begin{array}{l}\text { 2. LF UK - Ústav } \\
\text { vědeckých } \\
\text { informací }\end{array}$ & 5 & 1 & 3 & 1 & 4 & 0 & 14 \\
\hline $\begin{array}{l}\text { 3. LF UK - } \\
\text { Středisko } \\
\text { vědeckých } \\
\text { informací }\end{array}$ & 3 & 0 & 1 & 0 & 0 & 0 & 4 \\
\hline $\begin{array}{l}\text { Středisko } \\
\text { vědeckých } \\
\text { informací LF UK } \\
\text { a knihovna FN }\end{array}$ & 0 & 1 & 3 & 4 & 0 & 0 & 8 \\
\hline $\begin{array}{l}\text { Lékařská } \\
\text { knihovna LF UK } \\
\text { v HK }\end{array}$ & 0 & 0 & 0 & 0 & 0 & 1 & 1 \\
\hline $\begin{array}{l}\text { Knihovna } \\
\text { Fakulty } \\
\text { zdravotnických } \\
\text { věd UP }\end{array}$ & 1 & 0 & 0 & 0 & 0 & 0 & 1 \\
\hline $\begin{array}{l}\text { Oborová } \\
\text { knihovna } \\
\text { Lékařské fakulty } \\
\text { UP }\end{array}$ & 1 & 0 & 1 & 0 & 0 & 0 & 2 \\
\hline $\begin{array}{l}\text { UK FaF- } \\
\text { Středisko } \\
\text { vědeckých } \\
\text { a knihovnických } \\
\text { informací }\end{array}$ & 2 & 0 & 0 & 0 & 0 & 0 & 2 \\
\hline Celkem & 24 & 22 & 8 & 5 & 4 & 1 & \\
\hline
\end{tabular}

Tabulka 1 
Z výsledků analýzy vyplynulo, že vlastní tutoriály vytvářejí pouze knihovny lékařských fakult, VŠ zařízení a integrovaných pracovišt' (viz tabulka č. 1). Celkem se na stránkách těchto knihoven nachází 64 tutoriálů a to z následujících oblastí:

- elektronických informačních zdrojů a vyhledávání (39 tutoriálů),

- služeb (3 tutoriály),

- technického vybavení knihovny (9 tutoriálů),

- citování a citovanosti (7 tutoriálů)

- a jiných (6 tutoriálů).

Zdravotnické knihovny pro tvorbu tutoriálů využívají všechny formy vizualizací a jejich vzájemných kombinací. V kombinaci textů a snímků je vytvořeno nejvíce tutoriálů (24 tutoriálů). Pomocí této formy vizualizace vytvárí své tutoriály celkem sedm z devíti zdravotnických knihoven. Nejvíce tutoriálů v této podobě má na svých stránkách Knihovna univerzitního kampusu MU (10 tutoriálů). Další velmi využívanou vizuální formou jsou interaktivní videa. Na stránkách třech zdravotnických knihoven, vytvářejících vlastní tutoriály, existuje celkem 22 interaktivních videí. Opět nejvíce interaktivních videí má na svých stránkách Knihovna univerzitního kampusu MU (20 tutoriálů). [3]

\section{Doporučení vyplývající z analýzy}

\subsection{Formáty}

Při analýze bylo zjištěno, že knihovny mohou mít potíže s vkládáním tutoriálů na webové stránky. Ukazuje se, že nejvíce problémů se vyskytuje u formátu interaktivních videí. Všechna analyzovaná interaktivní videa jsou ve formátu SWF, který pro spuštění potřebuje Adobe Flash Player. To s sebou přináší dvě komplikace: pro některé uživatele může být nainstalování a povolení přehrávání flash $v$ prohlížeči nepřekonatelnou překážkou. Navíc, pro mobilní zařízení, například se systémy Android, je instalace ještě složitější, protože Adobe Flash Player v současnosti není k dispozici ke stažení v obchodě Google Play. Druhou komplikací je, že tento formát přestane být prohližeči v roce 2020 úplně podporován [7]. Interaktivní videa však Ize na web vkládat také ve formátu HTML5. Záleží však na programu, ve kterém je interaktivní video vytvořeno, zda umožňuje videa exportovat do tohoto formátu. Při analýze byla objevena také 3 videa ve formátu SWF, která nebyla vnořena do těla webové stránky, ale pro jejich spuštění bylo potřeba si nejprve celé video stáhnout a poté ručně nastavit jeho otevření v prohlížeči. Běžný uživatel však nemusí vědět, že formát SWF je možné otevřít a přehrát pomocí internetových prohlížečù.

Problémové se jeví také tutoriály ve formátech DOCX, PPTX apod., které je potřeba před jejich čtením stáhnout a otevř́t v príslušném programu, čímž se uživatelé vystavují bezpečnostnímu riziku. Obtíže však mohou mít hlavně uživatelé, kteří nevlastní balíček programů Microsoft Office. Nejspolehlivější metodou vkládání tutoriálů na webové stránky, se proto jeví vkládání tutoriálů prímo do těla webové stránky, nebo jde-li o text a obrázky, do formátu PDF.

\subsection{Délka}

Pomocí analýzy byla také sledována délka jednotlivých tutoriálů. $U$ různých forem vizualizací lze sledovat různé parametry určující rozsah tutoriálů. V textu Ize sledovat počet znaků, ve videu zas délku trvání videa atd. Všeobecně však platí, že je-li tutoriál př́liš dlouhý, je doporučeno jej rozdělit do více částí. Korientaci pak může uživateli pomáhat hypertextový obsah nebo menu.

\subsection{Dostupnost}

Tutoriály by měly být pro uživatele lehce dostupné, proto je vhodné umístit tutoriály na více míst. Nejdůležitější je vystavit tutoriály do míst, kde je uživatelé budou pravděpodobně nejvíce potřebovat. Lze také doporučit umístění tutoriálů tak, aby byly všechny přehledně dostupné z jednoho místa. Centralizovaný prístup ke všem návodům měly pouze dvě knihovny: knihovna univerzitního kampusu MU a Ústav vědeckých informací 1. LF UK a VFN.

\subsection{Aktualizace}

Tutoriály je také potřeba neustále aktualizovat a doplňovat. Záleží však na změnách obsahu, jehož se tutoriály týkají. Zejména v oblasti elektronických informačních zdrojů a vyhledávání dochází $\mathrm{k}$ neustálým změnám ve vyhledávacích prostredích. $Z$ celkového počtu nalezených tutoriálů bylo pouze 28 tutoriálů mladších 5 let. Nejstarší tutoriál pochází z roku 2005 a nejvíce tutoriálů vzniklo v roce 2016 (9 tutoriálů).

\section{Tutoriály v rámci e-learningového vzdělávání knihovníků}

Národní lékařská knihovna je specializovanou knihovnou, která má statutem mj. definovánu také činnost vzdělávací. Programem celoživotního učení do roku 2020 jsou definovány i cílové skupiny tohoto vzdělávání, patří k nim nejen uživatelé, ale i knihovníci zdravotnických knihoven. Nabízí se tak přiležitost sdílet již vytvořené tutoriály mezi samotnými knihovníky, ale i jejich další šíření mezi uživatele.

Národní lékařská knihovna od roku 2010 ve spolupráci s UK provozuje e-learningové kurzy pro neformální vzdělávání lékařských knihovníků. Cílovou skupinou jsou lékařští a zdravotničtí knihovníci, kurzy mají inovační charakter, jsou tutorované a provozovány jsou v LMS Moodle. Hlavním vzdělávacím cílem je prohlubovat znalosti v oblasti knihovnicko-informačních systémů, v prístupech a vyhledáváních specializovaných informačních zdrojů. Tato elektronická podpora vzdělávání se osvědčuje pro možnost snadné a průběžné aktualizace výukového materiálu, pro kontinuální přehledné a variabilní hodnocení výsledků učení na straně učitele i na straně studenta, pro samostatnost v rozhodování a možnost užívání interaktivních nástrojů.

Při prípravě e-kurzů jsou využívány metodické postupy publikované v disertační práci J. Feberové "Systém strukturované tvorby kurzu a hodnocení jeho kvality“ [2]. V části kurzu o „technologické oblasti“ je věnována pozornost vzdělávacímu prostředí, grafickému rozhraní kurzu, technickým požadavkům, optimalizaci prýstupu, tvorbě manuálů a užití multimédií [2]. Jako používaná forma učební opory dosud byly užívány převážně screenshoty, $v$ průběhu kurzu se však zejména $v$ modulech věnovaných vyhledávacímu prostředí, objevovaly $v$ dotazech tutorům otázky týkající se neporozumění výkladu. V tutoriálu, který jsme připravili pro letošní kurz Medicínské informace pro knihovny 2018, bude jako forma vizualizace tutoriálu využito interaktivní video pro simulaci postupů při vyhledávání.

\section{Závěr}

Rozhodnutí vytvářet tutoriály by měla nejdřive provázet rozvaha o jejich obsahu a vhodnosti zvolené formy a u každé respektovat její specifika. Každá z forem tutoriálů má své nástrahy, kterým se však dá vyhnout pečlivým plánováním. Nejen, že je potřeba správně zvolit danou formu, ale také její formát a jeho možnosti umístění na web (jinak je možné zacházet s formátem $A V I$ a jinak s SWF). Předem je potřeba počítat se změnami prostředí, kterých se tutoriály týkají a tedy i s nutností změn v tutoriálech (screenshot se dá vyměnit daleko rychleji než sekce snímků ve videu). Při plánování je na prvním místě vždy potřeba uživatele, který by se $\mathrm{k}$ tutoriálu měl snadno dostat a to tehdy, když jej bude potřebovat a v co nejkratší době. A co je nejpodstatnější, tutoriály by měly být uživatelům srozumitelné. 
Nástroje, které se dají používat pro tvorbu tutoriálů, se rychle inovují a jejich ovládání je stále jednodušší, proto je možné očekávat, že tutoriály budou ve vzdělávání v budoucnu více užívány.

\section{Literatura:}

[1.] Adresár̆ knihoven a informačních středisek zdravotnických zařizení České republiky za rok 2016. Praha: Národní lékařská knihovna, 2010-. ISBN 978-80-86823-04-1.

[2.] FEBEROVÁ, Jitka. Použití Learning management systému v univerzitním prostředí: Aplikace pro lékařskou informatiku a stomatologii. Praha, 2011. Dostupné také z: https://is.cuni.cz/webapps/zzp/detail/120239\%. Disertační práce. Karlova univerzita, 2. lékařská fakulta. Vedoucí práce Tatjana Dostálová.

[3.] MAŠKOVÁ, Klára. Analýza tutoriálů pro vyhledávání v informačních zdrojích českých zdravotnických knihoven. Praha, 2018. Bakalářská práce. Karlova univerzita, Filosofická fakulta, Ústav informačních studií a knihovnictví. Vedoucí práce Iva Zadražilová.

[4.] MARTIN, Nichole A. a Ross MARTIN. Would You Watch It? Creating Effective and Engaging Video Tutorials. Journal of Library \& Information Services in Distance Learning [online]. 2015, 9(1-2), 40-56 [cit. 2017-11-21]. DOI: 10.1080/1533290X.2014.946345. ISSN 1533-290x. Dostupné z: http://www.tandfonline.com/doi/full/10.1080/153329 $\underline{\text { OX.2014.946345 }}$

[5.] MESTRE, Lori S. Designing effective library tutorials: a guide for accommodating multiple learning styles. Oxford: Chandos Publishing, 2012. Chandos information professional series. ISBN 978-1-78063-325-1. Dostupné také z: http://site.ebrary.com/lib/natl/ Doc?id=10815671

[6.] PAPÍK, Richard. Informační profesionálové a knihovníci budou ovlivněni ve vzdělávání nastupujicími tématy informační společnost a informační ekonomiky. Duha : informace o knihách a knihovnách z Moravy [online]. 2015, 29(4), 13-18 [cit. 2018-02-13]. ISSN 0862-1985. Dostupné z: http://duha.mzk.cz/clanky/informacni-profesionalove-knihovnici-budou-ovlivneni-ve-vzdelavani-nastupujicimi-tematy-infor

[7.] Saying goodbye to Flash in Chrome. Blog Google [online]. Google, O2017 [cit. 2018-02-013]. Dostupné z: https://www.blog.google/products/chrome/saying-goodbye-flash-chrome/

[8.] SVËTLÁ, Jindra. Návod jako slohový postup a typ textu. Naše řeč [online]. 2002, 85(3), 119-129 [cit. 2018-02-13]. ISSN 0027-8203. Dostupné z: http://nase-rec.ujc.cas.cz/archiv.php?art=7681

\section{Kontakt:}

\section{PhDr. Eva Lesenková, PhD.}

Národní lékařská knihovna

Sokolská 54

12132 Praha 2

telefon: 296335932

e-mail: lesenkova@nlk.cz

https://nlk.czl

\section{Bc. Klára Mašková}

Národní lékařská knihovna

Sokolská 54

12132 Praha 2

telefon: 296335937

e-mail: maskova@nlk.cz, https://nlk.cz/ 